\title{
A bibliographical description of the British Library copy of The Honour of Chivalrie (1598)
}

\author{
María J. Sánchez-de-Nieva \\ Universidad de Sevilla
}

\begin{abstract}
This paper presents a detailed bibliographical description of the copy held at the British Library of the first edition of The Honour of Chivalrie (London, 1598; STC 1804). The aim of this paper is to provide useful bibliographical information for researchers interested in the first English translation of the Spanish romance Don Belianís de Grecia (Burgos, 1547; IB 8699). A concise description of the translations and editions of this romance is included.

KEYWORDS: Renaissance chivalric literature; Iberian romances of chivalry; The Honour of Chivalrie; Thomas Creede; Bernard Alsop; Francis Kirkman; Don Belianís de Grecia.
\end{abstract}

\section{Introduction}

The Spanish romance of chivalry Hystoria del magnánimo, valiente e inuencible cauallero don Belianís de Grecia. Primera y Segunda Parte by Jerónimo Fernández was first published in Seville in $1545 .{ }^{1}$ It soon became a literary phenomenon, which prompted the publication of new editions throughout the second half of the sixteenth century.

\footnotetext{
${ }^{1}$ The first extant edition of Part I and II is from 1547 . However, there seems to be evidence that supports the existence of a previous edition from 1545 - now lost - that would be the princeps edition of Fernandez's work. For a discussion on this, see Lucía Megías (2002:49) and Eisenberg and Marín Pina (2000:264). Orduna, however, considers it a ghost edition (1997:XVI).
}

$$
\text { (C) ederi 24 (2014: 171-179) }
$$

https://doi.org/10.34136/sederi.2014.9 
There are four extant editions: Burgos, Martín Muñoz, 1547 (IB 8699); Estella, Adriano de Anvers, 1564 (IB 8700); Zaragoza, Domingo de Portonaris y Ursino, 1580 (IB 8702); Burgos, Alonso y Esteban Rodríguez, 1587 (IB 8703). ${ }^{2}$ In addition to its popularity with Spanish audiences, in the eighty years following its initial publication it was translated into Italian, English and French. The first translation of the first part of Belianís de Grecia was into Italian by Orazio Rinaldi, printed in Ferrara by Vittorio Baldini in 1586 (USTC 829027), on whose version the English translation is based. The second part was also translated by Orazio Rinaldi and printed in Verona by Sebastiano dalle Donne in 1587 (USTC 829028). ${ }^{3}$ In the first quarter of the seventeenth century Fernández's romance was translated into French from the original Castilian by Claude De Bueil, and printed by Du Bray in Paris in 1625 (B 509). A second edition was published by Gilbert Saulnier, sieur Du Verdier between 1626 and 1629 (not in B) in Paris.

English translators and printers, in search of new titles to enlarge the catalogue of chivalric romance, turned to Spanish libros de caballería. Thus, the first part of Belianis de Grecia appeared as The Honour of Chivalrie set down in the History of Prince Don Belianis. With his love towards the Princess Florisbella, entered to the printer Thomas Creede in the Stationers' Register in 1598 (STC 1804). ${ }^{4}$ The title page notes that it was "Englished out of Italian" by a translator signing himself as L.A. Regarding his identity, very little is known. In the copy held at The Folger Shakespeare Library - one of the three extant copies of the 1598 edition - the handwritten signature of one

\footnotetext{
${ }^{2}$ For a discussion of the genre of Iberian romances of chivalry, see Thomas (1920); for a detailed bibliography see Eisenberg and Marín Pina (2000); also consult the on-line database prepared by Cacho Blecua and Lacarra, "Amadís: base de datos de literatura caballeresca" (http://clarisel.unizar.es/). Fernández's romance Hystoria del magnánimo, valiente e inuencible cauallero don Belianís de Grecia is available in a scholarly edition (Orduna 1997). I am currently preparing a critical edition of The Honour of Chivalrie for my doctoral dissertation. Research for this article was carried out as part of the project "Del Manuscrito a la imprenta: Estudio de la evolución de las adivinanzas y el romance en Inglaterra desde la Edad Media al Renacimiento" (PogHUM-5186), funded by the Andalusian Government.

${ }^{3}$ For a discussion of chivalric romances in Italy, see Bognolo (2010).

${ }^{4}$ For biographical information on Creede, see Gants (2004), Plomer (1907:3) and Yamada (1994:3-4).
} 
Lawrence Ashwel appears in the dedicatory letter. ${ }^{5}$ The same initials L. A. sign the seventh and eighth book of The Myrrour of Knighthood, published in 1598-1599 (STC 18869, 18870), based on the Spanish romance of chivalry Espejo de principes y cavalleros (1555), by Diego Ortúñez de Calahorra. ${ }^{6}$

This first translation of The Honour of Chivalrie was reprinted in 1650 (Wing STC F781) by Bernard Alsop, "dwelling in Grub-street neer the upper Pump." Alsop had been partner with Thomas Creede in 1616 at the sign of the Eagle and Child, and appears to have inherited his printing materials a year after (Plomer 1907:3-4). This edition shows a change in the dedicatee: instead of John Rotherham, "one of the sixe Clarkes of her Maiesties most Honourable Court of Chauncery," the second edition is dedicated to Arthur Anslow, heir of Sir Richard Anslow, "a worthy member of the Parliament of England." In 1663 (Wing STC F782) a third edition was probably printed by Elizabeth Alsop and Thomas Fawcet, Bernard Alsop's partner. From 1653 Elizabeth Alsop, widow of Bernard Alsop, is found running the printing house (Plomer 1907:4, 72). In 1664 (Wing STC K633), the second part of The Honour of Chivalrie was "newly written in English" by Francis Kirkman and printed by his partner Thomas Johnson in Southwark, London. Kirkman was a bookseller, printer, and collector of chivalric romances since his early years (Bald 1943; Newcomb 2004; Plomer 1907:110-111). The second edition of the second part of The Honour of Chivalrie was printed in 1671 (Wing STC K633A, K633B). In 1673 Kirkman wrote a third part and issued a volume containing the three parts of The Honour of Chivalry (Wing STC K634). In his preface to the reader Kirkman claims that this collection is "Compleat in three parts." However, it is interesting to note that, while the second and third parts are Kirkman's original works, the first part has been rewritten and the result is a systematic paraphrase throughout of the 1598 translation signed by L. A. The original fifty chapters conforming the 1598 edition are reduced to seventeen, in which numerous incidents,

\footnotetext{
${ }^{5}$ Extant copies of the first edition include: B. L. Huth.6o; Huntington Library 34016; Folger Library STC 1804.

${ }^{6}$ A scholarly edition by Joyce Boro of the first English translation of Margaret Tyler's Mirror of Princely Deeds and Knighthood (1578) has been recently published by the Modern Humanities Research Association (MHRA). For a critical edition of Espejo de principes y caballeros [El cavallero del Febo], see Eisenberg (1975).
} 
descriptions, and details are left unmentioned, while others have been rewritten. An example will show Kirkman's version of the original rendering. In the 1598 translation, Chapter 1 begins:

When the Grecian Monarchie flourished with most glorie, triumphing over the greatest part of Christendome, as is recorded in the large annuall Registers of Fristone (surnamed the Wise) preservers of the never dying fame, and ever memorable acts of the worthies of this time: There then soly swaied the awful imperious Crowne and Septer, an Emperour named Don Bellaneo, who through his rare vertues, gentle affabilitie, gallant conditions, royall and heroycke deedes, his admirable regard, and most great care in the administration of equall justice to his subjects, not taking the ones right to make the other rich, was of them so highly admired, loved, and reverenced, that the superfluitie of words in revealing it, would impoverish rather then inrich the pertuitie of his never dying glorie. (sig. $\mathrm{Bi}^{\mathrm{r}}$ )

By contrast, the beginning of Chapter 1 of Kirkman's 1673 edition reads:

The great City of Constantinople, whose Foundation was laid, and stately buildings erected by the Emperor Constamine, who made it the Metropolis of the Grecian Empire, had not enjoyed many Emperors before that Imperial Crown and Septer was swayed by one named Don Bellaneo, and such an emperor he was, both for strength of body, and all other Princely Endowments as was hardly equaled by any of his Predecessors, and was excelled by none. (sig. $\mathrm{BI}^{\mathrm{r}}$ )

This textual evidence shows Kirkman's departure from the original translation. The first part in the 1673 edition is a summary of the 1598 rendering, in which large sections of the narrative are omitted. Kirkman's rewriting of this first part can be understood as a necessary step towards producing a new collection of the adventures of Don Bellianis.

In 1678 (Wing STC F783) a reprint of the first part was issued for Thomas Passinger. And in 1683 (Wing STC F784) there appeared another edition containing three parts: the second and third written by John Shurley and printed for Thomas Passinger at the Three Bibles on London-Bridge (Burns 2004). A reprint of the edition was issued in two volumes for Ebenezar Tracy in 1703. From this point on, and throughout the eighteenth century, only chap-book abridgments of Shurley's edition were issued, with the only 
exception being the 1792 edition, printed in three parts in Dublin by R. Cross.

\section{Bibliographical Description}

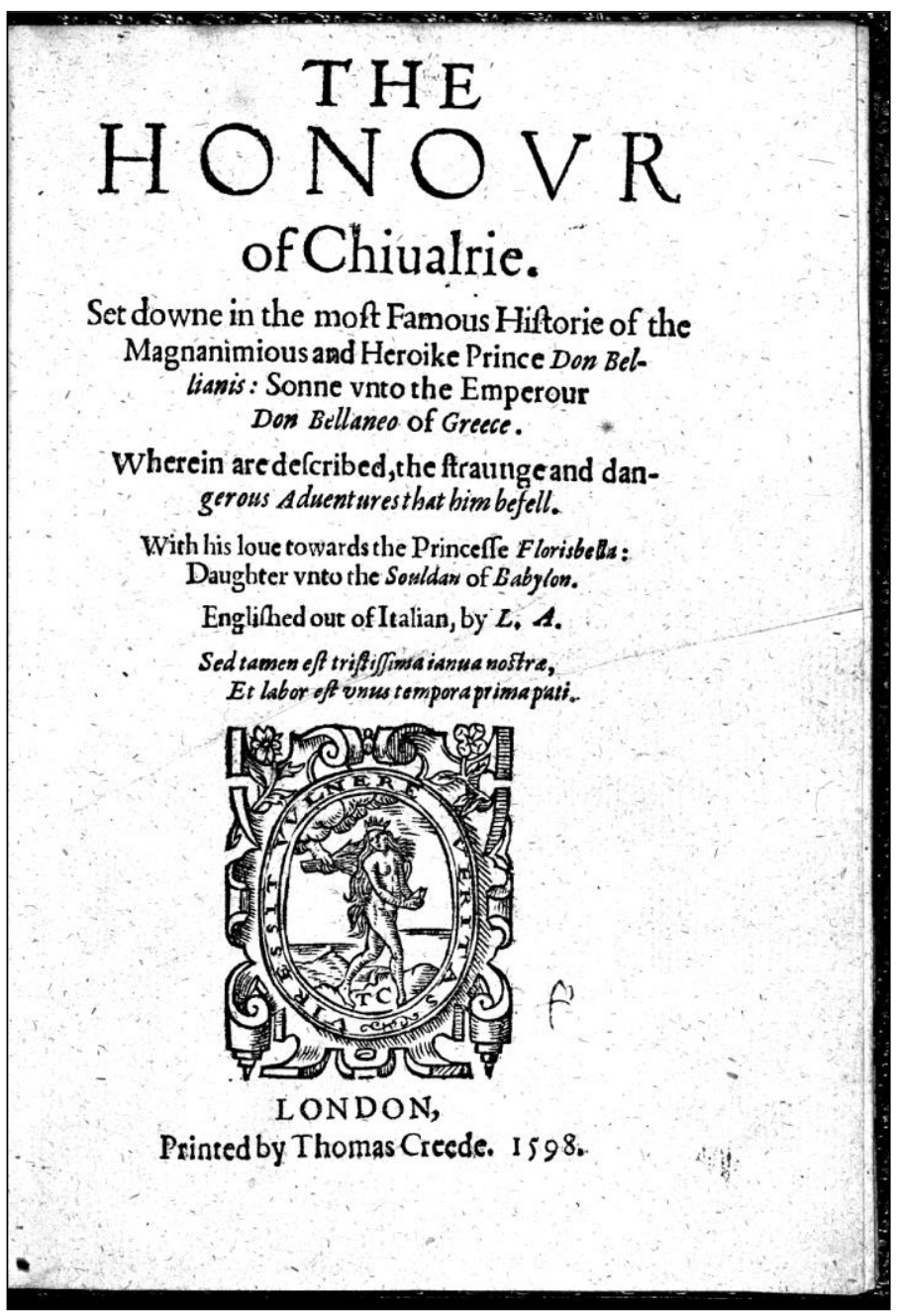

Figure 1. Title page of The Honour of Chivalrie (1598). () British Library Board, Huth.6o 
Title-page: THE HONOVR | of Chiualrie.|Set downe in the moft Famous Hiftorie of the |Magnanimious and Heroike Prince Don Bel|lianis: Sonne vnto the Emperour|Don Bellaneo of Greece.| Wherein are defcribed, the ftraunge and dan-|gerous Aduentures that him befell. With his loue towards the Princeffe Florisbella:|Daughter vnto the Souldan of Babylon.|Englifhed out of Italian, by L. A.|Sed tamen eft triftifima ianua nostrae,|Et labor eft unus tempora prima pati.|[orn. Yamada 1] |LONDON, |Printed by Thomas Creede. 1598.

Head-title: [orn. Yamada 23] The Honor of Chiualrie, $\square$ fet downe in the moft famous Hiftorie of the $\square$ Inuincible Prince Don Bellianis, fonne vnto the Em- $\square$ perour Don Bellaneo of Greece, wherein are defcri$\square$ bed his aduentures, and loue towards the Princeffe $\square$ Florisbella, Daughter to the Soldane $\square$ of Babilon.

Running-title: The Honour $\mathrm{Q}$ of Chiualrie. [honour $\mathrm{K}_{2}{ }^{\mathrm{v}}, \mathrm{K}_{3}{ }^{\mathrm{v}}$, $\mathrm{Aa}_{2}{ }^{\mathrm{v}}$; Honour. $\left.\mathrm{Mm}_{3} \mathrm{v}, \mathrm{Mm}_{4}^{\mathrm{v}}\right]$

Collation: $4^{\circ}: \mathrm{A}-2 \mathrm{O}^{4}\left[\$ 4\left(-\mathrm{A} 2,2 \mathrm{O}_{4}\right)\right.$ signed; misprinting $\mathrm{Ee}_{3}$ as E3]; 143 leaves, pp. [8] 1-286.

Contents: $\mathrm{A} 1$ (blank). $\mathrm{A} 2^{\mathrm{r}}$ : title-page (verso blank). $\mathrm{A} 3^{\mathrm{r}}$ : [orn. Yamada 12] $\square$ 'To the right Worlhip- $\square$ full his fpeciall Patron, Maifter Iohn Rotherham, $\mathrm{E}$ Efquire, one of the fixe Clarkes of her $\square$ Maiefties moft Honourable Court $\mathrm{u}$ of Chauncery.' ital. with 7 -line initial. $\mathrm{A}_{3}^{\mathrm{v}}$ : dedication ending 'Your Vvorships humblie deuoted. $\mathrm{C}$ L. A.' A4${ }^{\mathrm{r}}$ : [orn. Yamada 23] 'To all gentle Readers.' rom. with 6-line initial. Bi ${ }^{\mathrm{r}}$ $\mathrm{Oo}^{\mathrm{v}}$ : HT and text [b.1.], chap. 1-50. chap. hd. in rom. except for proper names. $\mathrm{Oo}^{\mathrm{v}}$ : 'FINIS.'

Catchwords: $\mathrm{D}_{1}^{\mathrm{r}}$ quake: [quake,] $\mathrm{E}_{4}^{\mathrm{r}}$ knight [Knight] $\mathrm{E}_{4}^{\mathrm{v}}$ Theffalie, [the] $\mathrm{H}_{3}{ }^{\mathrm{r}}$ fight, [hir] $\mathrm{H}_{4}^{\mathrm{v}}$ imaginations, [imaginations] $\mathrm{I}^{\mathrm{v}}$ actions. [actions:] $\mathrm{K}_{3}{ }^{\mathrm{v}}$ bee- [beeing] $\mathrm{L}^{\mathrm{v}}$ Gy [gyant] $\mathrm{L}_{2}^{\mathrm{r}}$ layd [laid] $\mathrm{L}_{4}^{\mathrm{v}}$ wife [wife,] $\mathrm{M}_{4}{ }^{\mathrm{r}}$ Where- [whereupon] $\mathrm{O}_{4}{ }^{\mathrm{v}} 2 \mathrm{O}$ [twenty] $\mathrm{Q}_{4}^{\mathrm{r}}$ (procrea-) ted a thing [a] $\mathrm{R}_{2}{ }^{\mathrm{r}}$ battel [battell] $\mathrm{S}_{4}{ }^{\mathrm{v}}$ Trulie [Truly] $\mathrm{T}_{1}^{\mathrm{v}} \operatorname{Tr}$ (damaged) at [at] $\mathrm{T}_{4}{ }^{\mathrm{r}}$ After [At] $\mathrm{U}_{3}{ }^{\mathrm{r}}$ see [to] $\mathrm{U}_{4}{ }^{\mathrm{r}}$ Whereupon [Whereupon,] $\mathrm{X}_{2}{ }^{\mathrm{v}}$ notwith- [notwithftanding] $\mathrm{X}_{3}{ }^{\mathrm{r}}$ knight, [knight] $\mathrm{X}_{3}{ }^{\mathrm{v}}$ Do. [Don] $\mathrm{Y}_{4}{ }^{\mathrm{v}}$ contrarie, [contrarie] $\mathrm{Aa}^{\mathrm{v}} \mathrm{com}^{-[c o m m a u n d]} \mathrm{Ee}^{\mathrm{r}}$ at- [attended,] $\mathrm{Hh}_{2}{ }^{\mathrm{V}}$ Knight [a] $\mathrm{Hh}_{4}{ }^{\mathrm{r}}$ wgerein [wherein] $\mathrm{Ii}_{4}{ }^{\mathrm{v}}$ mmoake [moake,] Kk3${ }^{\mathrm{v}}$ vnto [the] $\mathrm{Ll}_{4}{ }^{\mathrm{r}}$ with- [withdrew] $\mathrm{Mm}_{3}{ }^{\mathrm{r}}$ kingdome [Kingdome,] $\mathrm{Mm}_{4}{ }^{\mathrm{r}}$ $\mathrm{D}$ [Doo] $\mathrm{Nn}_{1}{ }^{\mathrm{r}}$ would [Don] $\mathrm{Nn}_{3}{ }^{\mathrm{r}}$ There- [Hereuppon] Oo ${ }^{\mathrm{r}}$ County [Count] 
Typography: The title page, the dedicatory epistle, and the preface are set in roman-letter types. This type is also used for chapter titles, the initial capital letters at the beginnings of chapter, proper names, and letters and inscriptions found in chapters 5, 40, and 41 . The bulk of the text is written in black letter (and some roman and italic). Chapter 29 misp. 6, chap. 30 misp. 4. Capitals used from Thomas Creede's stock (following Yamada 1994: 84-86): A1 (ch. $3,6,7,17,23,29)$, D1 (ch. 10, 12, 22, 24, 26, 27, 34, 36), E1 (sig. A4 ${ }^{\mathrm{r}}$ ), I1 (ch. 5, 11, 35), M1 (ch. 15), N1 (ch. 2, 16), S1 (sig. A3 ${ }^{\mathrm{r}}$, ch. 9, 25), T1 (ch. 4, 8, 13, 14, 18, 28, 37), W1 (ch. 1, 30, 33).

Size: The covers measure $140 \times 187 \mathrm{~mm}$. The leaves measure 132 x $179 \mathrm{~mm}$. Each page contains an average of 35 lines of type. Catchwords and signature markings, when they appear, are positioned on the $36^{\text {th }}$ line. Maximum printed space, with catchwords and signature marks is $86 \times 158 \mathrm{~mm}$; without catchwords is $86 \times 153 \mathrm{~mm}$.

Binding: The binding is of dark blue Morocco with gilt decorated border to upper and lower covers. Spine raised with ornamental gilt design. The title, HONOUR | OF | CHIUALRIE, appears in gilt lettering on the spine. On the bottom of the spine appears the date 1598 in gilt lettering. The fore-edges are gilt. Four blank leaves are added by the binder at the front and the back of the volume, plus one original leaf at the front and the back, forming a book of 296 pages. The first and the last leaves are also used for the front and rear pastedowns. This printing is on laid paper, with horizontal chain lines.

Watermarks: Odd number leaves added by binder are watermarked with letters "LV G", and even number leaves are watermarked with a fleur-de-lis on a crowned oval form.

Provenance: The front pastedown bears a blue and gilt oval stamp with the inscription "EX MVSÆO HVTH II". The stamp of the British Museum, on ( $\left.\mathrm{Oo}_{3}^{\mathrm{v}}\right)$, bears the date of acquisition 12 Dec 1911.

Condition of copy: In good condition. There are some small holes on several pages, probably caused by humidity or worms. There are also some stains on $\left(\mathrm{CCI}^{\mathrm{r}}\right)$, but the text is legible. 


\section{References and abbreviations}

Arber, E. ed. 1875-1894. A Transcript of the Registers of the Company of Stationers of London, 1554-1640 A.D. 5 vols. London, v. 191.

B > See Goldsmith (1973)

Bald, R. C. 1943. "Francis Kirkman, Bookseller and Author." Modern Philology 41/ 1: 17-32.

Bognolo, Anna 2010. "Libros de caballería en Italia." Amadís de Gaula, 1508: quinientos años de libros de caballerías. Madrid, Biblioteca Nacional de España, Sociedad Estatal de Conmemoraciones Culturales: 333-341.

Boro, Joyce. ed. 2014. Margaret Tyler, Mirror of Princely Deeds and Knighthood. London: Modern Humanities Research Association, 2014.

Bowers, Fredson 1949. Principles of Bibliographical Description. Princeton: Princeton University Press.

Burns, F. D. A. 2004. "John Shurley (fl. 1681-1702)." Oxford Dictionary of National BiographyEd. Lawrence Goldman. Oxford: Oxford University Press. <url: http://owww.oxforddnb.com.fama.us.es/view/article/25430>. Last accessed 23/10/2013.

Cacho Blecua, Juan Manuel and María Jesús Lacarra. "Amadís. Base de datos de literatura caballeresca." Clarisel. Universidad de Zaragoza. <url: http:/ / clarisel.unizar.es $\geq$. Last accessed 23/10/2013.

$\mathrm{CNCE}=$ Censimento nazionale delle edizioni italiane del XVI secolo. Vol. VI: EF. Roma: ICCU, 2007.

Eisenberg, Daniel, ed. 1975. Espejo de príncipes y caballeros [El cavallero del Febo]. 6 vols. Madrid: Espasa-Calpe.

— and $\mathrm{M}^{\mathrm{a}}$ Carmen Marín Pina 200o. Bibliografia de los libros de caballerías castellanos. Zaragoza: Prensas Universitarias de Zaragoza.

Gants, David L. 2004. "Creede, Thomas (b. in or before 1554, d.1616)." Oxford Dictionary of National Biography. Ed. Lawrence Goldman. Oxford: Oxford University Press. <url: http://o-www.oxforddnb.com.fama.us. es/view/article/6666>. Last accessed 23/10/2013.

Goldsmith, Valentine F. ed. 1973. A short title catalogue of French books, 16011700: in the Library of the British Museum. Folkestone and London: Dawsons of Pall Mall.

IB > Wilsinson (2010)

Lucía Megías, José Manuel 2002. "Libros de caballerías castellanos: textos y contextos." Edad de Oro XXI: 9-6o.

Newcomb, L. H. 2004 "Kirkman, Francis (b. 1632, d. in or after 1680)." Oxford Dictionary of National Biography. Ed. Lawrence Goldman. Oxford: Oxford 
University Press. <url: http:/ /o-www.oxforddnb.com.fama.us.es/view / article/15672>. Last accessed 23/10/2013.

Orduna, Lilia E. F. de, ed. 1997. Hystoria del magnánimo, valiente e inuencible cauallero don Belianís de Grecia. 2 vols. Kassel: Reichenberger.

— 1997. Introducción. Hystoria del magnánimo, valiente e inuencible cauallero don Belianís de Grecia. By Jerónimo Fernández. Kassel: Reichenberger: XIII-LXXIV.

— 1989. "En torno a la auténtica princeps de Belianís de Grecia." Incipit 9: 99102.

Plomer, H. R. 1907. A Dictionary of the Booksellers and Printers who were at work in England, Scotland and Ireland from 1641 to 1667. London: Bibliographical Society.

Pollard, A.W. and G.R. Redgrave comp. 1976-1991. A Short-Title Catalogue of Books Printed in England, Scotland and Ireland 1475-1640. 3 vols. 2nd ed. Rev. W.A. Jackson, F.S. Ferguson, and Katharine F. Pantzer. London: Bibliographical Society.

STC > Pollard and Redgrave (1976-1991)

Thomas, Henry 1920. Spanish and Portuguese Romances of Chivalry: The Revival of the Romance of Chivalry in the Spanish Peninsula, and Its Extension and Influence Abroad. Cambridge: Cambridge University Press.

USTC = Universal Short Title Catalogue. <url: http://www.ustc.ac.uk>. Last accessed: 20/10/2013.

Wilkinson, Alexander S. ed. 2010. Iberian Books: Books Published in Spanish or Portuguese or in the Iberian Peninsula before 1601. Leiden: Brill.

Wing, D. ed. 1982-1998. Short-Title Catalogue of Books Printed in England, Scotland and Ireland, Wales and British America and of English Books Printed in Other Countries 1641-1700. 4 vols. 2nd ed., rev. New York: Modern Language Association of America.

Wing STC > Wing (1982-1998)

Yamada, Akihiro 1994. Thomas Creede: Printer to Shakespeare and His Contemporaries. Tokyo: Meisei University Press.

How to cite this note:

Sánchez-de-Nieva, María J. "A bibliographical description of the British Library copy of The Honour of Chivalrie (1598)." SEDERI 24 (2014): 171-179.

Author's contact: sela@us.es

Submission: 30/10/2013 XXX

Acceptance: 05/03/2014 XXX 